Отримано: 17 квітня 2018 р.

Прорецеензовано: 26 квітня 2018 р.

Прийнято до друку: 05 травня 2018 р.

e-mail: t.pysmenna@tneu.edu.ua
Письменна Т. В. Практика антикризового фінансового управління в умовах збитковості економічної діяльності вітчизняних підприємств. Наукові записки Національного університету «Острозька академія». Серія «Економіка» : науковий журнал. Острог : Вид-во НаУОА, червень 2018. № 9(37). С. 152-156.

Письменна Тетяна Валеріївна,

кандидат економічних наук, доцент кафедри фінансів суб'єктів господарювання і страхування,

Тернопільський начіональний економічний університет

\title{
ПРАКТИКА АНТИКРИЗОВОГО ФІНАНСОВОГО УПРАВЛІННЯ В УМОВАХ ЗБИТКОВОСТІ ЕКОНОМІЧНОЇ ДІЯЛЬНОСТІ ВІТЧИЗНЯНИХ ПІДПРИЄМСТВ
}

У статті проаналізовано показники збитковості економічної діяльності вітчизняних підприємств за останні роки. Визначено заходи, які призначені забезпечити попередню діагностику загрози банкрутства та фінансове оздоровлення підприємства. 3'ясовано основні антикризові інструменти, щзо реалізуються через кадрову, інноваиіийну, інвестиційну та маркетингову види політики підприємства. Встановлено ключові вимоги, яким має відповідати підсистема антикризового фінансового управління на підприємстві.

Ключові слова: економічна діяльність підприємства, збитковість економічної діяльності, антикризове фінансове управління, антикризові фінансові заходи, антикризові інструменти політики підприємства.

Письменная Татьяна Валериевна,

кандидат экономических наук, дочент кафедры финансов субъектов хозяйствования и страхования,

Тернопольский национальный экономический университет

\section{ПРАКТИКА АНТИКРИЗИСНОГО ФИНАНСОВОГО УПРАВЛЕНИЯ В УСЛОВИЯХ УБЫТОЧНОСТИ ЭКОНОМИЧЕСКОЙ ДЕЯТЕЛЬНОСТИ ОТЕЧЕСТВЕННЫХ ПРЕДПРИЯТИЙ}

В статье проанализированы показатели убыточности экономической деятельности отечественных предприятий за последние годы. Определены мероприятия, которые предназначены обеспечить предварительную диагностику угрозы банкротства и финансовое оздоровление предприятия. Уяснены основные антикризисные инструменты, которые реализуются через кадровую, инновационную, инвестиционную и маркетинговую виды политики предприятия. Установлены ключевые требования, которым должна отвечать подсистема антикризисного финансового управления на предприятии.

Ключевые слова: экономическая деятельность предприятия, убыточность экономической деятельности, антикризисное финансовое управление, антикризисные финансовые мероприятия, антикризисные инструменты политики предприятия.

Tetiana Pysmenna,

Ph.D., Lecturer at the Department of Finance of Business Entities and Insurance, Ternopil National Economy University

\section{ANTI-CRISIS FINANCIAL MANAGEMENT PRACTICE IN CONDITIONS OF DOMESTIC ENTERPRISES UNPROFITABLE ECONOMIC ACTIVITY}

The indicators of domestic enterprises operating at a loss in the recent years have been analysed. The authors have determined the measures intended to provide preliminary diagnostics of the bankruptcy threat and financial rehabilitation of the enterprise. The main anti-crisis tools have been determined; they are to be implemented through personnel, innovative, investment and marketing types of enterprise policy. The key requirements to the anti-crisis financial management subsystem of the enterprise have been established.

Key words: economic activity of enterprise, unprofitable economic activity, anti-crisis financial management, anti-crisis financial measures, anti-crisis tools of enterprise policy.

Постановка проблеми. У сучасному вітчизняному бізнес-середовищі доволі часто висловлюють думку, що фінансове управління суб'єктом господарювання обов'язково має бути антикризовим, тобто базуватися на врахуванні небезпеки виникнення кризових ситуацій. Таку думку обгрунтовують неефективністю більшості традиційних підходів до фінансового управління суб'єктом господарювання. Побудова системи фінансового управління без урахування такої складової може загрожувати переходом 
на мікрорівні від потенційної кризи до ліквідації суб'єкта господарювання, а на макрорівні - від проблем у його діяльності до дестабілізації економічної системи у цілому. 3 огляду на це, вчасне виявлення проблем у діяльності суб'єкта господарювання та застосування антикризових фінансових заходів до них набувають важливого значення.

Аналіз останніх досліджень і публікацій. Останнім часом вітчизняні науковці почали приділяти посилену увагу питанням, пов'язаним із функціонуванням системи антикризового фінансового управління на підприємствах. Зокрема, окреслена проблематика об’єднала і наукове коло І. Бланка, В. Гринчуцького, Л. Ляхович, О. Островську, М. Романишина, Н. Сарай, О. Хандій та інших. Їхні наукові інтереси пов’язані 3 дослідженням причин виникнення кризових ситуацій на підприємстві; видів антикризових фінансових заходів; антикризових інструментів інноваційної, інвестиційної, маркетингової та кадрової політики підприємства; особливостей підсистеми антикризового фінансового управління підприємством тощо.

Попри те, що окреслена вище проблематика, зважаючи на свою актуальність, знайшла широке обговорення у працях вітчизняних учених, уважаємо за необхідне вкотре звернутися до неї та дослідити ііі 3 огляду на показники, які демонструють вітчизняні підприємства за результатами економічної діяльності.

Мета і завдання дослідження. Перед науковим дослідженням було поставлено мету, яка полягає в аналізі практики антикризового фінансового управління в умовах нестабільності економічної діяльності вітчизняних підприємств. Для досягнення цієї мети потрібно було вирішити такі основні завдання: проаналізувати показники збитковості економічної діяльності вітчизняних підприємств за ряд останніх років; визначити види заходів 3 антикризового фінансового управління підприємством; з'ясувати склад антикризових інструментів різних видів політики підприємства; встановити вимоги до побудови підсистеми антикризового фінансового управління на підприємстві.

Виклад основного матеріалу. За підтвердженням статистичних даних, за останні роки фінансові результати діяльності вітчизняних підприємств формувалися під впливом різних видів кризи. Йдеться, насамперед, про економічну та суспільно-політичну кризи, через які значна кількість підприємств отримала статус збиткових. За словами дослідників цієї проблематики, до такого статусу може призвести стан фінансової кризи на підприємстві, що ототожнюється з його неплатоспроможністю, діяльністю в неприбутковій зоні, браку в суб'єкта господарювання потенціалу для успішного функціонування [6, с. 124].

Із даних у таблиці 1 видно, який обсяг чистого прибутку або збитку отримали підприємства, здійснюючи різні види економічної діяльності, у 2010-2016 рр. Так, у 2010-2012 рр. і 2016 р. вітчизняні підприємства за результатами економічної діяльності отримували прибутки, середній розмір яких складав 36338,7 млн грн. Натомість, у 2013-2015 рр. результати економічної діяльності вітчизняних підприємств були від’ємними, тобто збитки становили, відповідно, 22839,7, 590066,9 і 373516,0 млн грн.

Обсяг чистого прибутку (збитку) підприємств за видами економічної діяльності у $2010-2016$ рр.

Таблиия 1 (млн грн)

\begin{tabular}{|l|c|c|c|c|c|c|c|}
\hline \multicolumn{1}{|c|}{ Види економічної діяльності } & $\mathbf{2 0 1 0}$ & $\mathbf{2 0 1 1}$ & $\mathbf{2 0 1 2}$ & $\mathbf{2 0 1 3}$ & $\mathbf{2 0 1 4}$ & $\mathbf{2 0 1 5}$ & $\mathbf{2 0 1 6}$ \\
\hline \multicolumn{1}{|c|}{$\mathbf{1}$} & $\mathbf{2}$ & $\mathbf{3}$ & $\mathbf{4}$ & $\mathbf{5}$ & $\mathbf{6}$ & $\mathbf{7}$ & $\mathbf{8}$ \\
\hline Сільське, лісове та рибне господарство & 17170,5 & 25341,3 & 26787,2 & 14984,5 & 21481,3 & 102849,1 & 90160,4 \\
\hline Промисловість & 11594,7 & 31961,6 & 2592,4 & $-4181,1$ & $-178730,9$ & $-188267,9$ & $-29096,1$ \\
\hline Будівництво & $-5095,7$ & $-4580,1$ & $-1012,7$ & $-5893,2$ & $-27948,8$ & $-25861,9$ & $-10179,6$ \\
\hline $\begin{array}{l}\text { Оптова та роздрібна торгівля; ремонт авто- } \\
\text { транспортних засобів і мотоциклів }\end{array}$ & 7547,4 & 12070,8 & 210,6 & $-13248,5$ & $-133219,4$ & $-88161,0$ & $-4750,7$ \\
\hline $\begin{array}{l}\text { Транспорт, складське господарство, пошто- } \\
\text { ва та кур'єрська діяльність }\end{array}$ & 1348,7 & 2839,8 & 3127,7 & $-1423,4$ & $-22591,6$ & $-17847,8$ & 7007,3 \\
\hline $\begin{array}{l}\text { Тимчасове розміщування й організація } \\
\text { харчування }\end{array}$ & $-633,6$ & $-692,4$ & $-984,3$ & $-1416,7$ & $-6641,9$ & $-6874,9$ & $-1896,0$ \\
\hline Інформація та телекомунікації & 2081,8 & 2068,6 & 3739,1 & 4881,5 & $-17137,1$ & $-12590,2$ & 1785,9 \\
\hline Фінансова та страхова діяльність & 11145,0 & 7916,9 & 10769,4 & 5157,1 & $-5550,3$ & $-9573,5$ & $-788,6$ \\
\hline Операції з нерухомим майном & $-7172,5$ & $-12852,2$ & $-9338,0$ & $-10192,2$ & $-105425,7$ & $-64369,0$ & $-41200,6$ \\
\hline Професійна, наукова та технічна діяльність & $-20279,1$ & 8267,5 & $-1820,2$ & $-8390,3$ & $-100347,2$ & $-48656,0$ & 25036,8 \\
\hline $\begin{array}{l}\text { Діяльність у сфері адміністративного та до- } \\
\text { поміжного обслуговування }\end{array}$ & $-1802,8$ & $-2490,7$ & 3576,4 & $-1555,2$ & $-9543,2$ & $-9860,6$ & $-6528,7$ \\
\hline Освіта & 56,3 & 75,4 & 112,8 & 119,0 & 62,5 & 80,7 & 85,6 \\
\hline $\begin{array}{l}\text { Охорона здоров’я та надання соціальної } \\
\text { допомоги }\end{array}$ & $-99,8$ & $-218,0$ & $-77,3$ & $-149,7$ & $-1185,3$ & $-1042,3$ & 33,5 \\
\hline Мистецтво, спорт, розваги та відпочинок & $-1930,3$ & $-1904,2$ & $-2547,6$ & $-1495,2$ & $-3244,0$ & $-3566,3$ & $-1301,3$ \\
\hline Надання інших видів послуг & $-24,5$ & $-6,4$ & $-68,2$ & $-36,3$ & $-45,3$ & 225,6 & 215,5 \\
\hline Усього & 13906,1 & 67797,9 & 35067,3 & $-22839,7$ & $-590066,9$ & $-373516,0$ & 28583,4 \\
\hline
\end{tabular}

Примітка. Складено автором на основі [10]. 
Щодо тих суб’єктів господарювання, які здійснюють фінансову та страхову діяльність, то впродовж 2010-2013 pр. вони отримували прибутки, а у 2014-2016 pp. - збитки. За розрахунками, середній обсяг прибутків таких суб'єктів господарювання становив 8747,1 млн грн, а середній обсяг збитків 5304,1 млн грн.

Візьмемо до уваги ще один показник, який характеризує рівень збитковості економічної діяльності вітчизняних підприємств, - це питома вага підприємств, які одержали збиток відповідної суми. Впродовж 2010-2016 рр. показник знаходився в межах від 26,7\% у 2015 р. до 42,7\% у 2010 р. Поряд з цими значеннями, питома вага підприємств, які одержали прибуток, дорівнювала 73,3\% у 2015 p. і 57,3\% у 2010 p.

Доволі часто говорять, що банкрутство підприємства $є$ наслідком тих суттєвих помилок, які допускає його керівництво у фінансовому менеджменті. Натомість, в умовах сьогодення підприємці розглядають кризу з фатальним настроєм, сприймаючи іiі як закономірне явище, що викликане впливом зовнішніх кризоутворюючих чинників. Водночас вони не зважають на вплив внутрішніх кризоутворюючих чинників, що також може призвести до погіршення фінансового стану підприємства. Тому в умовах проходження кризових явищ економічна поведінка підприємців позбавлена активності та грунтується на очікуванні ідеальних умов для господарювання [2, с. 31].

3 огляду на зазначене вище, у процесі антикризового фінансового управління підприємством слід враховувати, по-перше, внутрішні параметри його діяльності, тобто симптоми кризових явищ у межах самого підприємства, а по-друге, не обходити увагою зовнішнє середовище діяльності підприємства, а саме загрози кризових явищ із боку держави, конкурентів тощо [2, с. 32].

Доречно продовжити, що при антикризовому фінансовому управлінні підприємством можуть здійснюватися першочергові та середньострокові заходи. Перші з них спрямовуються на обмеження основних кризоутворюючих впливів зовнішнього середовища, а реалізація других сприяє стабілізації фінансового стану підприємства, підтриманню його конкурентних переваг [2, с. 32].

У процесі антикризового фінансового управління підприємство може здійснюватися заходи, зображені на рис. 1. У комплексі такі заходи забезпечують попередню діагностику загрози банкрутства та фінансове оздоровлення підприємства.

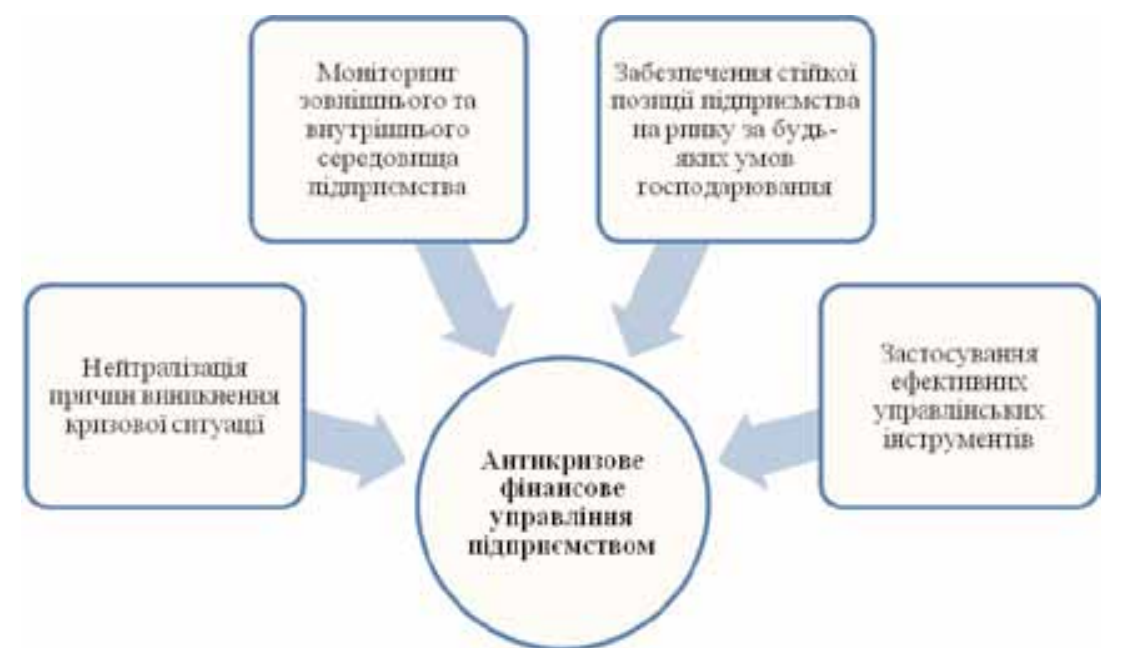

Рис. 1. Заходи з антикризового фінансового управління підприємством

Примітка. Побудовано автором на основі [2, с. 31].

Під час антикризового фінансового управління підприємством можуть здійснюватися різні за змістом заходи, що обумовлено глибиною і масштабом кризового становища. Зокрема, за умов відносно успішної діяльності підприємства слід проводити профілактичні заходи, спрямовані на попередження фінансової кризи, а за їі обставин - заходи, націлені на виведення підприємства 3 фінансової кризи [3, с. 17].

Щодо превентивних заходів, які націлені на нейтралізацію загрози фінансової кризи, то їх прикладами можуть бути такі: зменшення обсягу фінансових операцій, які проводять на найбільш ризикових напрямах фінансової діяльності підприємства; здійснення внутрішнього та зовнішнього страхування фінансових ризиків, які пов’язані з факторами, що формують загрозу фінансової кризи; реалізація активів підприємства, які є в надлишку або не використовуються, з метою збільшення резервів фінансових ресурсів; перетворення дебіторської заборгованості й еквівалентів грошових коштів у грошову форму [1, c. 598].

Загалом усі заходи, які націлені стабілізувати фінансовий стан підприємства, передбачають проведення змін у структурі капіталу, активів, грошових потоків, джерел формування фінансових ресурсів, інвес- 
тиційного портфеля підприємства. Завдяки здійсненню таких заходів буде усунуто неплатоспроможність підприємства, відновлено його фінансову стійкість, а також забезпечено стійке зростання підприємства в довгостроковій перспективі [1, с. 600].

Для того, щоб з'ясувати склад основних антикризових інструментів, варто спершу пригадати внутрішні причини виникнення кризових ситуацій на підприємстві. Це прийняття менеджерами помилкових стратегічних або тактичних рішень, ігнорування потреби у здійсненні модернізації та реструктуризації на підприємстві, недоліки в організації виробничого процесу, а також недосконалість різних видів політики суб'єкта господарювання - фінансової, кадрової, інноваційної, інвестиційної та маркетингової [9, c. 187].

Вище було згадано про внутрішню причину кризового стану підприємства - недосконалість кадрової політики, яку вважають однією з найголовніших. Ї̈̈ прояв відбувається через недостатню кваліфікацію персоналу, високу плинність кадрів, неефективні методи роботи, мікроменеджмент в управлінні, необгрунтоване збільшення кількості працюючих і витрат на оплату їхньої праці, некомпетентність керівництва. Через важливість цієї причини виділяють антикризові інструменти, які реалізуються через кадрову політику. Необхідність у застосуванні таких інструментів пояснюють тим, що управлінські рішення на підприємстві приймаються та реалізуються за участю персоналу, тому всі проблеми, які виникають усередині підприємства, є наслідками дій або бездіяльності того ж персоналу [9, с. 187; 189-190].

Водночас антикризові інструменти, як це визначено, можуть реалізуватися також через інноваційну, інвестиційну та маркетингову політику підприємства. Їх уважають дієвими інструментами не тільки подолання кризових ситуацій на підприємстві, а й забезпечення сталого розвитку суб' єкта господарювання в довгостроковій перспективі [9, с. 189, 191; 5, с. 103-105].

Правильно говорять, що в умовах прискорення науково-технічного прогресу, посилення конкуренції між учасниками товарного ринку зростає роль інновацій у діяльності підприємства. До того ж, здійснення нововведень за умов фінансової кризи на підприємстві можна вважати цінним антикризовим інструментом. Одночасно важливо забезпечити прийняття таких рішень, які дадуть змогу досягти поставленої цілі зі створення продукції, що має високий попит на ринку й, відповідно, гарантує отримання максимального прибутку [3, с. 19; 23].

Під час обгрунтування важливості антикризових інструментів інвестиційної політики наголошують на тому, що сьогодні для більшості підприємств інвестиції є єдиною можливістю, щоб оновити техніку та технологію виробництва, здійснити капітальний ремонт тощо. Крім того, інвестиції вважають основним джерелом вирішення фінансових проблем підприємства, оскільки в умовах кризи амортизаційні відрахування використовуються для покриття нестачі оборотних коштів і забезпечення виробничого процесу матеріальними ресурсами, а при збитковості суб'єкт господарювання не може здійснювати фінансування діяльності за рахунок прибутку і кредитних ресурсів, які дорого вартують [9, с. 190].

Застосування антикризових інструментів маркетингової політики передбачає просування товарів на нові ринки, зміцнення позиції підприємства на старих ринках тощо. Такі інструменти застосовують відповідно до антикризових маркетингових програм, що є складовою частиною стратегічного і тактичного плану підприємства з виходу з кризи [8, с. 125].

Під час побудови підсистеми антикризового фінансового управління на підприємстві необхідно враховувати думки дослідників цього питання - як теоретиків, так і практиків, серед яких такі ключові позиції:

1. Сфера застосування антикризового фінансового управління має бути обширною, тобто охоплювати не тільки заходи, що здійснюють щодо підприємства-боржника в умовах банкрутства, а й заходи, які носять превентивний характер. Інші з них уважають ефективнішими, порівняно з першими, які спрямовані на усунення наслідків кризи на підприємстві.

2. У ході антикризового фінансового управління слід здійснювати не тільки заходи, спрямовані на виведення підприємства зі стану кризи, а й заходи, які дають змогу спрогнозувати такий стан і застерегти суб'єкта господарювання від нього. Другі з них переслідують стратегічні цілі, а перші забезпечують виконання поточних завдань.

3. Підсистема антикризового фінансового управління має бути активізована 3 часу створення суб'єкта господарювання. Тобто ще на початковому етапі функціонування системи управління підприємством мають враховуватися потенційні загрози настання кризи [4, с. 85-86].

4. Кожен суб'єкт господарювання самостійно розробляє та реалізує методи подолання кризової ситуації. Це відбувається в межах антикризової фінансової політики, яка враховує сферу діяльності, форму власності, розмір підприємства, а також наявні ресурси та можливості, реальний стан і рівень загрози [9, c. 189].

5. Як і будь-яка інша управлінська система, підсистема антикризового фінансового управління підприємством виконує функції прогнозування і планування, організації, мотивації, контролю. Виконання кожної з цих функцій передбачає застосування антикризових інструментів, які їй відповідають [7, с. 110].

Наукові записки Національного університету «Острозька академія», серія «Економіка», № 9(37), червень, 2018 р. 
Висновки. Отже, результати проведеного наукового дослідження засвідчують, що, по-перше, важливість антикризового фінансового управління підприємством найбільше проявляється в умовах частої змінюваності показників його економічної діяльності; по-друге, антикризова фінансова управлінська діяльність передбачає здійснення заходів різних видів, спрямованих на попередню діагностику загрози банкрутства підприємства, а також на його фінансове оздоровлення; по-третє, у процесі антикризового управління можуть застосовувати різні інструменти, склад яких обумовлюється видом політики підприємства - кадрової, інноваційної, інвестиційної та маркетингової; по-четверте, до побудови підсистеми антикризового фінансового управління на підприємстві ставляться вимоги, дотримання яких робить іiі особливою, тобто такою, що має цільове призначення.

Наприкінці зазначимо, що криза може по-різному впливати на підприємство - як негативно, так і позитивно. Справді, криза здебільшого має руйнівний характер, та, з другого боку, за кризою можуть слідувати прогресивні зміни в діяльності підприємства. Це відбуватиметься в тому разі, коли керівництво підприємства об'єктивно оцінить свої дії за наслідками кризової ситуації. 3 огляду на останнє, кризу доцільно розглядати також як поштовх до перетворень, які сприяють розвитку діяльності підприємства.

Відповідно до зазначеного вище, подальші наукові дослідження можуть стосуватися, зокрема, обгрунтування позитивного впливу кризи на суб'єкта господарювання. Таке дослідження дасть змогу не обійти увагою іншу складову такого явища як криза, розкрити iï потенціал у забезпеченні поступального розвитку суб'єкта господарювання. До того ж, дослідження в цьому напрямі буде мати елементи новизни, оскільки згадану наукову проблему не вважаємо повністю вирішеною.

\section{Література:}

1. Бланк И. А. Финансовый менеджмент: учебный курс. 2-е изд., перераб. и доп. К.: Эльга, Ника-Центр, 2004. $656 \mathrm{c}$.

2. Гринчуцький В. І., Ляхович Л. А. Антикризове фінансове управління підприємством в сучасних умовах господарювання. Інноваційна економіка. 2011. № 3. С. 28-33.

3. Камнєва А. В. Дослідження існуючих інструментів та моделей антикризового управління на підприємстві. Економіка та управління підприємствами машинобудівної галузі: проблеми теорї̈ та практики. 2014. № 4 (28). C. 15-26.

4. Островська О. Антикризове фінансове управління в умовах економічної нестабільності. Ринок иінних паперів України. 2009. № 5-6. С. 83-88.

5. Перерва П. Г., Косенко А. В., Косенко О. П. Антикризові інструменти сталого розвитку підприємства: інноваційна, інвестиційна та маркетингова політика. Вісник Наи. техн. ун-ту «ХПI». Харків, 2012. № 25. C. 100-106. URL: http://repository.kpi.kharkov.ua/bitstream/KhPI-Press/9964/1/vestnik_HPI_2012_25_ Pererva_Antykryzovi.pdf (дата звернення: 15.03.2018).

6. Романишин М. І. Фінансові кризи та кризові явища як загроза економічній стабільності підприємств. Вісник Національного університету «Львівська політехніка». 2010. № 682. С. 123-130.

7. Рубан В. М. Антикризові інструменти та основні функції антикризового менеджменту. Галицький економічний вісник. 2015. № 1 (48). С. 109-114.

8. Сарай Н. І. Сучасні маркетингові стратегії в антикризовому управлінні підприємством. Інноваційна економіка. 2014. № 1. С. 124-127.

9. Хандій О. О. Антикризові інструменти управління підприємством: практичні аспекти реалізації. Маркетинг і менеджмент інновацій. 2012. № 4. С. 186-192.

10. Чистий прибуток (збиток) підприємств за видами економічної діяльності у 2010-2016 роках. URL: http://www.ukrstat.gov.ua/ (дата звернення: 15.03.2018). 